Hallgeir Elstad og Dag Thorkildsen:

\title{
Hvilket kirkesyn gjenspeiler dåpsritualet fra 1889 til i dag?
}

Det er skrevet mye om liturgireformene fra 1889 og fremover, og det har rast mange debatter, også om utformingen av dåpsritualet. Men selve spørsmålet: Hvilket kirkesyn gjenspeiler dåpsritualet? - har primært blitt berørt på en indirekte måte. Derfor må en trekke inn andre typer kilder for å prøve å besvare spørsmålet. Det er i seg selv interessant fordi det gir en indikasjon på at dåpen innenfor vår norske tradisjon gjennom flere århundrer har spilt en mer underordnet rolle når det gjelder kirkesynet. For å si det enkelt: Dåpen er ikke tilstrekkelig, selv om den er en dåp til Jesu død og oppstandelse. Et typisk eksempel finner vi hos salmedikteren Brorson som i 1765 kunne spørre: «Av døpte vrimler stad og land, men hvor er troens brann?» via Gustav Jensen som mente at dåpen ikke hørte hjemme i den egentlige gudstjeneste, og fram til nyere tid hvor noen har hevdet at dåpen ikke kan ses som tilstrekkelig for å ha stemmerett ved valg til kirkelige råd.

Hvis vi vil ha svar på spørsmålet: Hvilket kirkesyn avspeiler dåpsritualet, må vi også se på hvordan man rent konkret praktiserer ritualet. Videre må vi spørre om hvilken status man gir dåpen, dvs. hvordan man omtaler og behandler de som er døpt. Er de b-medlemmer og misjonsmark eller fullverdige medlemmer av kirken? Til slutt må vi også spørre om forholdet mellom dåp og konfirmasjon.

\section{Fra reformasjonen til 1736}

Liturgireformen i 1889 representerte på ingen måte noe nytt. Bruddet kom først med Gustav Jensens forslag av 1914 og Alterboken av 1920. Forut for det går det en sammenhengende linje fra reformasjonens tid og til det 20. århundre. De lutherske reformatorene var nokså konservative når det gjaldt dåpsteologien. I Den augsburgske bekjennelses artikkel 9 fra 1530 leser vi om dåpen «at den er nødvendig til frelse, og at Guds nåde tilbys ved dåpen, og at barn bør døpes, og at de, når de ved dåpen er overgitt til Gud, mottas i Guds nåde». ${ }^{i}$ Derimot gjennomgikk dåpsliturgien en forsiktig revisjon og forenkling, som fjernet de mest magiske elementene i middelalderritualet. For dåpen var for Luther rettferdiggjørelsens sakrament. Det 
er Gud selv som suverent handler, og ikke noe kan legges til eller kreves i forhold til den nåde som Gud reelt meddeler i dåpen.

Videre kjempet Luther mot gjendøperne, og da uttrykte han seg enda sterkere, noe vi bl.a. ser i Den store katekisme. Her avviser han kontant alle forsøk på å spiritualisere dåpen, dvs. skille mellom det ytre tegn, vannet og ordet, og troen. Derfor blir mennesket reelt gjenfødt og nyskapt $\mathrm{i}$ dåpen. Troen gis $\mathrm{i}$ dåpen som en Guds gave.

Da reformasjonen ble innført i Danmark-Norge, skjedde det derfor ikke så mye med dåpen. Den viktigste endringen var at barna fra nå av skulle døpes på dansk og ikke på latin. Peder Palladius oversatte Luthers dåpsliturgi fra 1526, og utga den i 1538, mens den i 1556 ble tatt inn i den nye alterboken. ${ }^{\text {ii }}$ Denne ordning dannet kjernen i vår dåpsliturgi fram til

- fjernelsen av eksorsismen i 1783 ,

- $\quad$ en mindre revisjon i 1889

- og Gustav Jensens brudd med tradisjonen i 1914 og 1920.

Fra reformasjonen og til slutten av 1500-tallet begynte dåpen utenfor kirkedøren, hvor fadderne stod med barnet som bare var noen dager gammelt. For barnet skulle døpes innen åtte dager. Her på utsiden av kirken ble så den lille og den store eksorsisme utført. Etter den lille eksorsisme hvor presten bød den urene ånd å fare ut av barnet og gi rom for Den hellige ånd, tegnet han korstegnet på barnets panne og bryst. En rest av denne delen av dåpsritualet er fortsatt bevart i vår dåpsliturgi. Deretter fulgte den lange «syndeflodsbønnen», som henspilte på fortellingen om Noa og arken, om Israelsfolkets overgang gjennom Det røde hav og Jesu egen dåp i Jordanelven, for å uttrykke dåpens frelsende betydning. Deretter fulgte den store eksorsisme hvor den urene ånd ble drevet ut i den treenige Guds navn, samt lesningen av barneevangeliet hos Markus.

Den neste delen av dåpsliturgien foregikk inne i kirken, ved døpefonten som var plassert rett innenfor inngangsdøren, og mot slutten av 1500-tallet ble også eksorsismedelen flyttet inn hit. Presten innledet med «Gud bevare din inngang og din utgang fra nå og til evig tid». ${ }^{i i i}$ Deretter stilte han sju spørsmål til barnet i du-form om forsakelsen, om troen og om det ville bli døpt. Disse ble besvart av fadderne på vegne av barnet. Deretter kunne selve dåpen finne sted, og 
den ble fulgt av at presten ikledde barnet dåpsskjorten og en erklæring om dåpens gjenfødende virkning. Til slutt kom fadderformaningen, som understreket deres vitneansvar og ansvar for barnets kristne oppdragelse hvis foreldrene skulle $d \varnothing$ før barnet kom til skjels år og alder, slik det fortsatt er i vår danske søsterkirke.

Dette var altså hovedtrekkene i dåpsliturgien fra reformasjonen og fram til det 20. århundre århundre. Så kommer det store spørsmålet: Hvilket kirkesyn gjenspeilte dette dåpsritualet?

For det første gjenspeilte det dåpens enorme betydning for den enkelte, for kirken og for samfunnet. Barnet skulle døpes så raskt som mulig etter fødselen, slik at det kunne bli gjenfødt, fødsel og gjenfødelse hang tett sammen. For udøpte barn risikerte å gå fortapt, og dette var jo en tid med stor barnedødelighet. Dessuten kunne udøpte nedkalle Guds vrede over folk og land. Det store og skarpe skillet gikk altså mellom udøpte og døpte. Derfor foregikk første del av dåpsritualet utenfor kirken hvor det onde ble drevet ut av det udøpte barnet før det kunne tas inn i kirken. Her markerte neste del at barnet ble tatt opp i kirken, som i syndeflodsbønnen ble sammenliknet med Noas ark. Det konkrete tegn på barnets nye status som døpt og en del av kristenheten, var dåpsskjorten. Da man med tiden gikk bort fra hel neddykking, ble den avløst av den såkalte «Christen-Huen» (jf. Kirkeritualet av 1685).

\section{Fra dåp til konfirmasjon}

Den første store endring når det gjelder forståelsen av dåp og kirkesyn i vår kirke, kom ikke i form av en endring av dåpsritualet, men i form av innføring av konfirmasjonen som både endret dåpsforståelsen og svekket dåpens grunnleggende betydning for kirken. Dåpen var ikke lenger nok.

De lutherske reformatorene hadde forkastet læren om konfirmasjonen som en sakramental handling, fordi konfirmasjonen manglet guddommelig innstiftelse og svekket dåpens betydning. For dåpen trengte etter deres syn ikke noe tillegg eller fullstendiggjørelse. Alt ble gitt i den, og alle døpte var en del av den synlige kirke. Derfor hadde Luther vært svært skarp i karakteristikken av konfirmasjonen: Den var apespill og narreverk. Derimot la han stor vekt på undervisningen i Guds ord. Ingen skulle ta del i nattverden uten å bli prøvd på forhånd. Denne prøvingen bestod i at presten i det private skriftemål skulle forvisse seg om at 
vedkommende både bekjente sine synder og hadde den tilstrekkelige kunnskap til å forstå hva nattverden betydde i den kristne lære og det kristne liv.

Med reformasjonen ble altså konfirmasjonen erstattet av en prøving hvor vekten ble forskjøvet fra det sakramentale til det kunnskapsorienterte, samtidig som denne nye «ordning» ble knyttet til nattverden, ikke til dåpen. Det er bl.a. i denne sammenheng vi må se Luthers Lille katekisme som kom i 1529. Han hadde vært med på en visitas i menighetene i Sachsen og var forskrekket over folks uvitenhet, slik han skriver i forordet:

Å du gode Gud, all den elendighet jeg har sett! Den alminnelige mann, især på landsbygda, har ikke den minste kjennskap til kristenlæren, og mange sokneprester er dessverre ganske uskikket og udugelig til å undervise. Likevel skal alle kalles kristne, være døpt og få de hellige sakramenter, selv om de hverken kan Fader vår eller trosbekjennelsen eller de 10 bud, men lever som det kjære kveg og de vettløse griser. ${ }^{\text {iv }}$

Fra reformasjonen og fram til begynnelsen av 1700-tallet var slagordet derfor: ikke konfirmasjon, men katekisme - også her i Danmark-Norge. De unge måtte være over 12 år og kunne sin katekisme før de kunne gå til alters.

Det var pietismen som innførte en bekjennelseskonfirmasjon i reformasjonskirkene. Samtidig møtte den mye motstand, og i Sverige ble f.eks. konfirmasjonen ikke innført før i 1811. Den ene av pietismens to førende teologer, Philipp Jacob Spener (1635-1705), hadde i 1668 visitert den lille landsbyen Bonames ved Frankfurt am Main, og der fikk han oppleve en kirkehandling han aldri før hadde sett, en konfirmasjon med overhøring, bekjennelse og løfteavleggelse. Han anså dette som et ypperlig middel til å fremkalle syndserkjennelse og tro hos de unge. Under innflytelse av den pietistiske reformbevegelse ble derfor en liturgisk konfirmasjonsordning innført. Hensikten var for det første å sikre den offentlige kontroll av de unges kunnskaper. For det andre skulle dette være en offentlig bekreftelse av dåpspakten. Dermed var det teologiske fokus igjen vendt mot dåpen, ikke nattverden. Det sprang utav at pietismen nærmest anså barnedåpen som en ren seremoni og derfor ville ha bekjennelseskonfirmasjonen som den egentlige opptakelse i kirken. 
I Danmark-Norge kom det 13. januar 1736 en forordning som gjorde konfirmasjonen obligatorisk for alle. Her ble det slått fast at «Børnenes Confirmation og Indvielse saavel som deres offentlige Examen og Prøvelse skal være en almindelig Regel og skyldig Pligt, som alle Børnene udi Meenigheden [...] skal nødvendig være bundet til». ${ }^{v}$ Presten ble så pålagt å samle de unge i sitt hus og undervise dem i troens artikler. På konfirmasjonsdagen skulle han etter prekenen stille de unge opp i midtgangen. Etter en kort bønn og en tale «uten vidløftig harangveren» skulle han så overhøre dem og stille spørsmål til hver enkelt av dem. Når denne eksamen var slutt, begynte selve konfirmasjonen. Presten skulle først tale om den dåpens pakt de unge skulle gjenta. Så skulle han spørre hver enkelt om han eller hun forsakte djevelen og alle hans gjerninger og pomp. Dernest om hun/han av ganske hjerte trodde på «Gud Fader, Søn og Hellig Aand [...] for det tredje om han vil blive udi saadan sin Daabes Pagt indtil sin sidste salige Ende.» Poenget var at de unge skulle gjenta faddernes løfter og selv påta seg dåpens forpliktelse. Dette skulle så bekreftes med et håndslag, og dette løftet omtales derfor som en ed for Herren. Deretter skulle presten legge hånden på konfirmantens hode og lese konfirmasjonsformelen:

Den Tre-Eenige Gud, som fordum haver antage dig til sit Barn udi den Hellige Daab, og gjort dig til en Arving til det evige Liv, Han vilde opholde dig udi saadan din Daabes Naade, indtil din salige Ende; Han give dig Bestandighed i din Troe, din Siæl til Salighed. ${ }^{\mathrm{vi}}$

Konfirmasjonen kom på denne måten til å få to fokus: overhøringen og løfteavleggelsen. Den var ingen frivillig handling, men på samme måte som dåpen en borgerplikt med klare sivilrettslige følger.

Hvis vi spør: Hvilket kirkesyn gjenspeilte denne reformen, blir svaret at fokus ble flyttet fra dåpen som et uttrykk for Guds suverene nåde og opptakelsen av barnet i kirken, til konfirmasjonen som uttrykk for en bevisst bekjennelse og dermed opptakelse i kirken. Dåpen var blitt redusert til en foreløpig pakt som først trådte i kraft når barnet var blitt så gammelt et det selv kunne bekrefte pakten etter å ha gjennomgått en opplæring $i$ «frelsens orden». Dåpen var altså ikke lenger nok, men noe foreløpig, og troen ble ikke gitt i dåpen som en Guds gave, men måtte vekkes gjennom undervisning og formaning. 


\section{Fra 1736 til 1914/20}

Noen større endringer av selve dåpsliturgien i vår kirke kom imidlertid ikke før i 1783. Da ble de to eksorsismer og Luthers syndeflodsbønn fjernet ved en kongelig forordning. ${ }^{\text {vii }}$ I stedet skulle presten holde en innledende, formanende tiltale, som sammen med en rekke bibelsitater skulle fastholde de samme motiver som i de ledd som nå ble utelatt. Men dette førte til at denne bønnen ble svært lang, og i de neste hundre år kom det flere forslag om å forkorte eller utelate den. For sammen med spørsmålene om forsakelse og tro som skulle rettes til hvert enkelt barn, førte dette til at dåpshandlingen kunne ta svært lang tid når så mange som 20-30 barn skulle døpes på en gang.

I tillegg til kravet om et kortere dåpsritual var det kritikken av barnedåpen og dåpstvangen som kom til å prege 1800-tallets dåpsdebatt. Denne kritikken hadde sin bakgrunn i den begynnende frikirkelighet og i vekkelsenes gjennombrudd. Dette var for så vidt to sider av samme sak. For en del av de frikirkelige kritiserte barnedåpen fordi det ikke var tale om noen bevisst bekjennelse fra barnets side, mens vekkelsens folk hevdet at dåpen ikke var nok, det måtte senere også skje en bevisst omvendelse og bekjennelse. Når det gjaldt selve dåpsritualet, dreide den sterkeste striden seg om oversettelsen av Apostolicum, nærmere bestemt oversettelsen av den tredje trosartikkels tale om kirken. Spørsmålet som ble stilt til barnet, lød: «Tror du paa den Hellig-Aand? en hellig christelig Kirke at være, som er hellige Menneskers Samfund osv?» Dette var en anstøtssten for grundtvigianerne, som jo i sterk grad bygde sin kirkelige anskuelse på Apostolicum i den historisk opprinnelige utforming av bekjennelsen. Dette førte til at en del prester brukte en annen oversettelse enn den autoriserte, noe som igjen utløste klager fra menighetene. viii

Da debatten om liturgiene for høymessen og de kirkelige handlinger skjøt fart i 1880-årene, ble det høsten 1885 oppnevnt en komité for å behandle forslag til en reform som var utarbeidet av Hesselberg og Gustav Jensen. Komitéen bestod av den nye kirkestatsråden Jakob Sverdrup, Gustav Jensen, prest og redaktør Andreas Michael Hansen og biskop Grimelund. Den var ferdig med sitt arbeid i 1887, og resultatet nedfelte seg i alterboken av 1889. ${ }^{\text {ix }}$ Så langt har vi tillagt Gustav Jensen mye av æren for denne revisjonen, og det med rette. Men når vi spør om det kirkesyn som kommer til uttrykk, er det en annen person som er vel så interessant og som i høyeste grad har preget Gustav Jensen, nemlig Andreas Grimelund. 
Grimelund hadde gjennom oppveksten og studietiden hatt en sterk tilknytning til herrnhuterne eller brødremenigheten. Herrnhuternes historiske opprinnelse er kompleks. Selv regner de den 13. august 1727 som sin fødselsdag for da ble det avholdt en stor felles altergang på kolonien Herrnhut (=Herrens omsorg) i Ober-Lausitz i Sachsen. Under ledelse av den merkelige grev Nicolaus Ludwig von Zinzendorf (1700-1760) spredde de seg så til store deler av den protestantiske verden. Det gjorde de ved å grunnlegge såkalte sosieteter, en type religiøse foreninger, som bl.a. drev med religionsundervisning etter moderne pedagogiske ideer, og $\mathrm{i}$ enkelte tilfeller grunnla de også nye kolonier. Her i Norden fikk herrnhuterne i 1771 lov til å anlegge en slik koloni på Sønderjylland, og den fikk navnet Christiansfeld. Den ble et viktig sentrum som spredde herrnhutisk propaganda, ikke minst i Danmark-Norge.

Den herrnhutiske fromhet er sterkt følelsespreget og sentrert rundt Jesu lidelse og død og forsoningen. Dette kommer til uttrykk i en blodmystikk og en naiv og søtladen Jesu-sentrisme med en erotisk bildebruk, hentet fra det ekteskapelige samliv, og som ender i en naiv modalisme, hvor Gud og Kristus nærmest blir identifisert med hverandre. Herrnhuterne forstod menigheten som et filadelfisk brodersamfunn, og et viktig kjennetegn på den sanne menighet var at man drev med misjon - både indre- og ytremisjon. Videre ble menigheten forstått som en indre og en ytre sirkel. Selv om man gjennom dåpen var opptatt i brødremenigheten, hadde man ikke uten videre adgang til nattverden. Man måtte søke om opptakelse i nattverdsfellesskapet og gå gjennom en viss prøvetid hvor man skulle oppfylle kravet om en personlig helliggjørelse. Nåden ble dermed forstått som en forvandlende kraft, og ikke først og fremst som Guds rettferdiggjørende handling. Og følgeriktig ble troen derfor definert som en fides caritate formata (tro formet av kjærlighet), og ikke først og fremst som Guds ufortjente gave.

I norsk teologi- og kirkehistorie har en viet disse herrnhuterne liten oppmerksomhet. Hvorfor, er det lett å besvare. Herrnhuterne har alltid nedtonet konfesjonelle forskjeller og har gjennom sin såkalte diaporavirksomhet uproblematisk kunnet operere innenfor ulike kirkesamfunn. I tillegg var det en bevisst strategi hos herrnhuterne ikke å bedrive offentlig debatt, ikke tiltrekke seg uønsket oppmerksomhet. De ville virke i det stille, som en surdeig. Derfor er det ikke så lett å tegne et historisk bilde av deres virksomhet. Det vi vet, er at de hadde etablert seg i Norge alt i slutten av 1730-årene, først i Christiania, så i Trondheim. Videre var det gjerne personer fra det vi kan kalle middel- og overklassen som på 1700-tallet stod i spissen 
for de såkalte sosieteter, og disse sosietene ble ofte beskyttet av prester, som var herrnhutsinnede. Godt kjent er biskop Peter Olivarius Bugge i Trondheim, som selv kom fra en herrnhutisk prestefamilie. I Kristiania hadde herrnhuterne sin glanstid i 1820- og 30-årene, takket være den virksomhet som brødre-agenten Niels Johannes Holm (1778-1845) fra Christiansfeld bedrev. Denne sosieteten publiserte oppbyggelsesskrifter, lærebøker og misjonsblader og opprettet omsorgsinstitusjoner. Holm selv deltok i arbeidet i den første bibelkomiteen i Kristiania, og han diktet salmer. En av dem heter karakteristisk nok: «Hvor salig er den lille flokk». Og kort sagt så ble denne brødresosieteten i Kristiania den første aktivitetsmenighet $\mathrm{i}$ vårt land. ${ }^{\mathrm{x}}$

Til denne Kristiania-sosieteten, som var preget av liv og aktivitet, strømmet de teologiske studenter i 1820- og 30-årene. En av dem var Andreas Grimelund. Fra han var 12 år gammel og i fire år hadde han bodd hos Holm og fått kristendomsundervisning i regi av brødresosieteten. Deretter hadde han i to år bodd hos den kjente herrnhuterpresten Gabriel Kielland på Finnø på Vestlandet, før han vendte tilbake til Kristiania for å studere teologi. Samtidig deltok han altså aktivt i byens herrnhutermenighet. Den samme Grimelund ble i 1861 utnevnt til biskop i Trondhjems stift, og i hans vita som ble lest opp ved vigslingen, skriver han «at de varme Vidnesbyrd om den lidende Frelser, som han hørte i Barneaarene i sin Opdragers Huus, gjorde et uutslettelig Indtryk paa hans Sind» og motiverte ham til å bli prest. Før han ble biskop, hadde Grimelund i begynnelsen av 1850-årene avløst Wilhelm Andreas Wexels som hovedlærer (dvs. rektor) på Det praktisk-teologiske seminar. Hva slags undervisning han ga de blivende prester, kjenner vi fra hans Forelasninger over practisk Theologie, som han utga i 1856 - det året han sluttet ved seminaret. Her møter vi et klart herrnhutisk farget menighetsbegrep. Noen av de mest talende eksemplene kan nevnes.

Alt i innledning til liturgikken som han definerer som læren om den kristelige kultus, kommer herrnhutismen til uttrykk. Og resten av hans behandling av dette emnet er nettopp sentrert rundt en forståelse av gudstjenesten som kult, som en mystisk forening av den troende og Gud. Derfor bestemmes kultus som en livsvirksomhet hvor «christelige Troesbekjendere komme menighedsviis sammen for Guds Ansigt for at udtrykke sin Afhængighedsfølelse og Ærefrygt for Gud». 
I denne kulten er - skriver Grimelund - menigheten både subjekt og objekt, akkurat slik Gustav Jensen senere kom til å hevde. Men hos Grimelund sies det altså med rene ord, også når det gjelder nattverden. Den er en handling $a v$ - ikke for - menigheten. Videre kommer hans menighetssyn til uttrykk ved at han skiller klart mellom de kultusdyktige og de ikkekultusdyktige. De kultusdyktige har et bevisst kristent trosliv og utgjør kommunionmenigheten - akkurat slik Gustav Jensen uttrykker det -, mens de ikke-kultusdyktige (dvs. de som bare er døpt) skal gjøres til gjenstand for «missionarisk Virksomhed», dvs. undervisning i de kristelige grunnsannheter i form av preken og katekese. Målet med prekenen bestemmer Grimelund som 1) å forkynne Kristus for oss - det er det lutherske perspektiv hos ham - og 2) å forkynne Kristus i oss - det er det herrnhutiske perspektiv hos ham.

På samme måte som Gustav Jensen skriver Grimelund at gudstjenestens høydepunkt og fullendelse er nattverden, og på god herrnhutisk maner beskrives den som «Herrens inderlige og fortrolige Samvær med sin Menighed og Forbildet paa den himmelske Menigheds salige Forening med Frelseren». Samtidig er den et uttrykk for fellesskapet i brodersamfunnet. Derfor må man holde de ikke-kultusdyktige borte fra nattverdbordet, og det skal skje bl.a. gjennom en formaningstale før nattverden. Overfor dette brodersamfunnet - eller kjernemenigheten - skal den kirkelige virksomhet være oppbyggende, mens den overfor de andre, de som bare er døpt, skal være misjonerende. Det er i denne sammenheng interessant å konstatere at Carl Fredrik Wisløff i sitt verk om norsk kirkehistorie hevder at nettopp Grimelunds pastorallære med dens spesielle menighetsbevissthet var en viktig forutsetning for at man kalte den private presteskole som ble opprettet i 1908, for nettopp Menighetsfakultetet. ${ }^{\text {xi }}$ Andre har her villet trekke en linje til Gustav Jensen, men det kommer ut på det samme.

Det er denne herrnhutisk inspirerte teologi vi altså må ha i mente når vi spør om kirkesynet i liturgirevisjonen av 1889. Det store stridsspørsmålet rundt revisjonen av dåpsliturgien av 1889 var om spørsmålene om forsakelse, tro og ønske om dåp skulle rettes direkte til barnet, eller om menigheten i fellesskap skulle framsi forsakelsen og troen. Grimelund og Gustav Jensen kjempet hardt for å bevare den gamle ordning med spørsmål rettet direkte til barnet.

Begrunnelsen var at barnet fra dåpen av riktignok ikke eier den fullt utviklete tro, men det har en trosgnist, en trosspire, en trosevne. Dåpen var derfor å anse som en pakt mellom Gud og barnet, og dette kunne bare fastholdes gjennom spørreformen. Etter dåpen skulle trosspiren vokse og utvikles med konfirmasjonen som mål. Da kunne barnet selv bekrefte dåpspakten og 
ta ansvaret for det løfte som ble avlagt i dåpen. Uten spørreformen ville derfor konfirmasjonen bli meningsløs. Grimelund skriver da også i sine Forelaesninger over practisk Theologie at «I Daaben blev et nyt Liv nedlagt hos Barnet, men det er endnu en uudviklet Spire». Derfor må det gjennom en oppdragelsestid.

I denne Opdragelsestid betragter Kirken Barnet som kirkelig umyndigt [...] Naar derimod Barnet er utdviklet til fuld Bevidsthed om sin Daabs Pagt og følgeligt istand til med fuld bevidst Selvbestemmelse at tilegne sig samme, da kommer Kirken til med den næste Initiationshandling: Konfirmationen. ${ }^{\text {xii }}$

Det var altså den individuelle, subjektive og psykologisk-spekulative siden ved dåpen som på denne måten ble fokusert, samtidig som hovedfokus ble konfirmasjonen med edsavleggelse. Dermed ble dåpens sakramentale karakter nedtonet, for ikke å si fjernet.

Kritikerne av spørreformen hevdet derimot at det var uholdbart at dåpen skulle ha en mystisk virkning på barnets naturside, som nok var å regne med, men likevel utilstrekkelig når barnet vokste opp. Dåpens virkning er ikke noe som skjer i barnet, men med barnet, hevdet de. Det utfris fra Djevelens rike og innlemmes i Guds rike. Dermed ble fokus rettet mot dåpens sakramentale og frelsende karakter. Men dette vant ikke fram i utformingen av det reviderte ritualet. Derimot ble antall spørsmål redusert. Det var altså Grimelunds og Gustav Jensens syn som fikk gjennomslag på dette punkt. Men Jensens forslag om å kaste dåpen ut av høymessen vant ikke fram. Den skulle foregå på den tradisjonelle plass hvis ikke menigheten ønsket noe annet, og biskopen godkjente dette.

Neste runde om dåpsritualet kom med Gustav Jensens forslag til nytt rituale i $1914 \mathrm{og}$ alterboken av 1920. ${ }^{\text {iiii }}$ Bakgrunnen var at det fra 1902 og fremover var kommet en rekke henvendelser til departementet om å endre dåpsritualet. Misnøyen rettet seg for det første mot en formulering i den innledende talen som kunne vekke uheldige fantasier: «dette Barn som er undfanget i Synd og født i Misgjerning». For det andre rettet den seg mot spørsmålsformen. Høsten 1911 fikk derfor Gustav Jensen i oppdrag å lage utkast til et nytt ritual bl.a. for dåpen, selv om han fortsatt mente at dåpen ikke hørte hjemme i høymessen. Det forslag han la fram, brøt radikalt med tradisjonen fra reformasjonen. Den lange innledende formaningen var 
redusert til en kort oppfordring, og dåpsbefalingen og barneevangeliet ble plassert helt i begynnelsen av handlingen for å understreke dåpens forankring i Skriften.

I dåpsformularet var «døber dig i Faderens», Sønnens og Den hellige Ånds navn endret til «døber dig til Faderens», Sønnens og Den hellige Ånds navn, slik det fortsatt er. Den greske preposisjonen som her er brukt i Matt. kap. 28, er «eis», som betyr «inni». I NT-oversettelsen av 1904 var dette blitt oversatt med nettopp «til», og Gustav Jensen oppga selv dette som den viktigste grunnen til endringen. Men det ble ikke mye debatt om dette spørsmålet, selv om forslaget ble kritisert på filologiske premisser. Det er derfor interessant å konstatere at da en dansk prest for noen år siden foretok en tilsvarende endring for å svekke dåpens sakramentale karakter, ble han avsatt. Grunnen kan naturligvis være at forskjellen på «i i det danske språk enn i det norske, men den kan også være at det i dansk teologi er en langt sterkere bevissthet om dåpens sakramentale betydning.

Helt nytt i Jensens forslag var velsignelsesønsket like etter dåpen: «Den allmektige Gud, vår Herre Jesu Kristi Fader, som har gjort deg til sitt barn i den hellige dåp og taget deg inn i sin troende menighet, han styrke deg med sin nåde til det evige liv! Fred være med deg.» Den tidligere ordlyd fokuserte på dåpen som syndstilgivelse. Gustav Jensen opplyste imidlertid selv at han ønsket å understreke dåpen som opptakelsen i menigheten. Derimot var uttrykket «sin troende menighet» nokså egenartet. Det har ikke forelegg i Apostolicum som taler om «en hellig, allmenn kirke», og heller ikke hos Luther, for da måtte det bli tale om «sin kristne menighet» eller «sin kristne kirke». Noen direkte forklaring på denne nye formuleringen har vi derfor ikke funnet. Men i sin høringsuttalelse uttalte Det teologiske fakultet at dette var en uheldig formulering, og det kan hevdes at det er Gustav Jensens mystiske og herrnhutisk inspirerte menighetsbegrep som her svever i bakgrunnen. For det kan ikke være Apostolicums tredje ledd.

Når det gjaldt Fader vår, begrunnet Gustav Jensen bønnens plassering med tradisjonen. Men han ville ha med en innledende formulering: «Lad os bede som Herren har lært sine». Den ble imidlertid sløyfet i den bearbeiding av dåpsritualet som biskop Støylen foretok i 1916. I denne sammenheng ble også følgende spørsmål tatt inn, rettet til foreldre og faddere: «Vil I at dette barn skal døpes til Faderens og Sønnens og Den hellige Ånds navn og opdrages i den kristne forsagelse og tro?» Det hang sammen med at nå var spørreformen ved forsakelsen og troen 
forlatt. Gustav Jensen hadde imidlertid kjempet heftig for å bevare den. Ved en kongelig resolusjon av 23. desember 1914 ble hans forslag likevel autorisert, men altså uten spørreformen. Den endringen frasa han seg offentlig ethvert ansvar for. For den svekket dåpens karakter av å være en pakt mellom Gud og barnet. I stedet for spørsmålene rettet til dåpsbarnet, skulle prest og menighet sammen framsi forsakelsen og troen. Dette leddet ble innledet med følgende ledd som vi fortsatt benytter: «Lad os bekjende forsakelsen og troen som vi døber våre barn til». Men denne oppfordringen har ikke fått noen heldig utforming, da det $\mathrm{i}$ forsakelsen ikke er tale noe som vi positivt bekjenner, men om noe som vi nettopp forsaker.

Ikke uventet kom det sterke protester fra den radikale del av vekkelsesfolket mot det nye dåpsritualet. De truet med å melde seg ut av kirken. Departementet måtte slå retrett og tillate bruk av det gamle ritualet, også når den nye alterboken kom i 1920.

Så kommer igjen det store spørsmålet: Hvilket kirkesyn gjenspeilte dette dåpsritualet? Det er tydelig at dåpen som opptakelse i menigheten ble understreket på en helt annen måte enn tidligere. Men det var tale om en betinget opptakelse, betinget av at barnet senere i forbindelse med konfirmasjonen skulle bekrefte dåpspakten. Derfor kjempet Gustav Jensen så sterkt for å beholde spørreformen, den skulle peke framover mot den bevisste bekjennelse som en gang skulle avlegges. Det døpte barns tilstand var ikke kjennetegnet av tro, for troen er betinget av den utvikling den døpte skulle gjennomgå mot personlig kristenliv, preget av det bevisste liv og den religiøse erfaring. Han kunne derfor skrive at barnestadiet tilsvarte den første trosartikkel eller disiplene før påsken. Mens det andre trinn, det personlige kristenliv, ble kjennetegnet ved bruddet med synden og en moralsk omvendelse som til slutt førte til en oppgivelse av selvet. I løpet av denne prosess ble frelsen forvandlet fra en gave til en oppgave.

Fokus i Gustav Jensens radikale revisjon var fortsatt Gud og den enkelte, og rammen om den enkelte var menigheten som de troendes fellesskap og det kristne hjem. Han ville helst ha understreket det siste enda sterkere i form av følgende ledd: «I forældre som nu begjærer at eders barn skal døbes med den kristne daab, og vil at det skal opdrages i den kristne tro, eder give Gud visdoms og gudsfrykts Aand, saa I med ord og gjerning fører eders barn til Herren og bereder det et kristent hjem i tro og kjærlighed, forat det naar det vokser op, maa blive ved Kristus som det i daaben bliver indpodet i ham». Men dette ble i løpet av prosessen utelatt. I 
stedet ble foreldrene inkludert i fadderformaningen, noe som var helt nytt. Tidligere ble foreldrenes rolle tatt som gitt.

\section{Fra 1914/20 til 1981-liturgien}

Dåpsritualet som ble vedtatt ved kongelig resolusjon av 23. desember 1914, og som bygde på Gustav Jensens forslag, ble med noen mindre forandringer tatt inn i alterboken av 1920. Dette dåpsritualet fikk et langt liv. I 1971 hadde liturgirevisjonen utarbeidet et utkast til ny liturgi, men det fikk ikke noen god mottakelse i en uoffisiell høringsrunde. Man mente det var for ordrikt og langt. Arbeidet med dåpsliturgi fortsatte, og et forslag til endelig utkast forelå i 1979. Dette ble i hovedsak vedtatt ved kongelig resolusjon av 24. april 1981. Denne kom med få endringer med i den nye gudstjenesteboken i 1992. ${ }^{\text {xiv }}$ På mange måter forsterker denne liturgien hovedtendensen i liturgirevisjonene fra 1889 og fra 1914/20.

Med 1981-litugien fikk dåpsritualet en mer liturgisk innledning ved at det startet med påkallelsen av den treenige Gud eller med nådeønsket. Det er interessant å konstatere at den første instans som nevnes, ikke er barnet eller foreldrene, men menigheten. Så kommer en forklaring på dåpens innhold som er todelt: den gir del i frelsen og opptakelse i kirken. Først etter dåpssalmen kommer den skriftmessige forankring av dåpen. En rest av motivene i den gamle syndeflodsbønnen er plassert først etter skriftlesningene. Deretter følger formaningen til foreldre og faddere. Som tidligere skal de være vitner om at barnet er døpt. Men i fortsettelsen innføres en tredje instans, menigheten og hele kirken. Til sammen skal disse ha ansvar for å be for barnet, lære det selv å be og bruke nådemidlene. Helge Fæhn, som har spilt en sentral rolle i etterkrigstidens liturgireformer, skriver at dette er uttrykk den nyere nådemiddel-teologi. ${ }^{\mathrm{xv}}$ Hvor treffende det er, er noe usikkert, iallfall hvis spørsmålet er hva som kommuniseres. At menigheten og kirken har et ansvar for dåpsopplæringen, er ikke noe nytt. Slik har det vært siden reformasjonen. Videre har målet for opplæringen vært nattverden. Men hva er det som kommuniseres med denne formaningen? Mange dåpsforeldre og faddere deltok jo ikke hvis det er nattverd i samme gudstjeneste som dåpen. Samtidig skal de altså lære barna å bruke nattverden når de vokser opp. Man kan derfor konstatere at den kirkelige virkelighet og de gode intensjoner bak ritualet ikke alltid var helt sammenfallende. En stygg fortolkning ville være at foreldre og faddere som selv ikke deltok i nattverden, ikke ble ansett som egnet til å ønske dåp av barnet. 
Forsakelsen og trosbekjennelsen var i 1981-liturgien knyttet tett til formaningen, og det var en heldig plassering. Man kunne imidlertid tenke seg at formaningen fikk en utforming som eksplisitt knyttet innholdet i den til trosbekjennelsen. Det ville i så tilfelle være mer i tråd med den sentrale rolle forsakelsen og troen spilte fram til $1914 \mathrm{og}$ fortsatt spilte for eksempel i den danske folkekirken. Videre ville det knytte an til spørsmålet som rettes til foreldre og faddere ved døpefonten.

Ny var også bønnen ved døpefonten som fremhevet elementet i dåpssakramentet og Den hellige ånds nyskapende og gjenfødende gjerning. Men en kan spørre: Ble det ikke på denne måten for mange motiver som for dogmatikkens skyld måtte være med? Man kan spørre hvor mange av de tilstedeværende som fikk med seg alt sammen og forstod det som ble sagt. Derfor ble det også tatt til orde for en forenkling, slik det også var blitt gjort på 1800-tallet. For Gustav Jensens løsning, å kaste dåpen ut av høymessen, var imidlertid ingen teologisk farbar vei. Når det gjelder selve dåpsformularet, beholdt man formuleringen som var blitt innført i 1914-liturgien, dvs. døpe til den treenige Guds navn.

Utformingen av velsignelsesønsket skapte det problem som Gustav Jensens uttrykk «den troende menighet» reiser. Derimot fungerer plasseringen av 1. Peter 1.3 til slutt før Fader vår godt, særlig hvis man også bruker dette skriftstedet etter jordpåkastelsen i begravelser. Da innrammer det menneskelivet fra dåpen til livets slutt.

Hvis vi igjen spør: Hvilket kirkesyn gjenspeilte 1981-liturgien, er vel svaret at det peker i litt ulike retninger. Grunnen er at det bygger på en lang tradisjon som har rommet ulike forståelser når det gjelder kirkesyn. Derfor blir det så viktig hvordan man konkret tilrettelegger dåpen. Ritualet inneholdt fortsatt levninger av det gamle eksorsismeleddet. Det er det i og for seg ikke noe galt i. Men det ble utformet innenfor en virkelighetsforståelse hvor verden som en kampplass mellom Gud og Djevelen var helt selvsagt. Verre er det hvis vi undergraver dåpens karakter av å være rettferdiggjørelsens sakrament. Heldigvis synes derfor den tidligere tette kobling av dåp og konfirmasjon å være svekket selv om den lever videre hos mange. Men verst av alt er det hvis vi bruker dåpen og dåpsritualet til å holde miniforedrag om dogmatikk som går langt over hodet til folk, hvor motivet er å få sagt alt det riktige uansett om dåpsfølger og menighet forstår det eller ikke. Da må vi huske på at den viktigste endring som kom med reformasjonen, var at barna ble døpt på et forståelig språk. 
Selv om skapelsesteologien har stått svakt når det gjelder tekstene i selve dåpsritualet, har dette i nyere tid blitt kompensert gjennom noen av de flotte og populære dåpssalmene som har blitt diktet, ikke minst av bl.a. Svein Ellingsen og Gerd Grønvold Saue. I økende grad ble imidlertid fraværet av skapelsesteologiske perspektiver i dåpsliturgien problematisert. Prester uttrykte en generell misnøye med liturgien. En undersøkelse fra 1989 viste at nesten en fjerdedel av prestene som var intervjuet, oppgav at de forandret på dåpsliturgien. Over halvparten av informantene sa at de fulgte liturgien, men gjorde det under tvil. Prestene syntes ikke liturgien fungerte godt, verken språklig, pedagogisk eller teologisk. Den var for tung og ordrik. $^{\text {xvi }}$

\section{Gudstjenestereformens dåpsliturgier}

I 2003 ble det gjort vedtak om en gudstjenestereform (liturgireform) i Den norske kirke. Denne trådte i kraft i 2011. ${ }^{\text {vii }}$ Som del av gudstjenestereformen ble det også påbegynt et arbeid med ny dåpsliturgi. Dette var den delen av reformen som tok lengst tid. Her var diskusjonene sterkest og uenighetene størst. Underveis i reformen oppstod en debatt i kirken om dåpens innhold. Særlig kom diskusjonen til å dreie seg om menneskesynet og fraværet av skapelsesteologisk fokus i den gjeldende dåpsliturgien. ${ }^{\text {xviii }}$

\section{8-liturgien}

Nemnd for gudstjenesteliv fremmet et forslag til endret dåpsliturgi i 2008, og denne utgjorde i neste omgang grunnlaget for dåpsliturgien som ble vedtatt av Kirkemøtet i 2011. 2008liturgien inneholdt en ny strukturering i tre deler: 1) Mottakelse, 2) dåpshandlingen, 3) livet i dåpen. Denne struktureringen bidro til å tydeliggjøre elementene som omgir selve dåpshandlingen. Mottakelsen til dåp ble en mer markert del av liturgien. I det første alternativet kom gleden og takken for barnet og det skapelsesteologiske aspektet tydelig til uttrykk: "Med takk og glede kommer vi (med NN) til Gud som har skapt oss (alle) i sitt bilde." ${ }^{\text {xix }}$ Den tredje delen vektla at dåpen også gjelder hele livet. Faddernes forpliktelser var lagt til denne delen, altså etter selve dåpshandlingen, slik den også var i 1920-liturgien. Lesningen av Joh. 3,16 var ikke lenger en fast del av liturgien - som i 1981-liturgien - men kom inn som ett av mange alternativer til bibeltekster i forbindelse med dåp av eldre barn og ungdom. De to faste tekstlesningene var de samme som liturgiene fra 1920 og 1981. Mark 10 (Jesus og barna) er riktignok flyttet fram og kommer rett etter mottakelsen til dåp. 
Nytt i forhold til tidligere er at det er kommet inn et nytt ledd, en takkebønn. Det er formulert tre alternativer til denne. Innholdsmessig inneholder disse en takk for livet og bønn for framtiden. Dette var med på å tydeliggjøre det skapelsesteologiske perspektivet. Den delen av liturgien som omhandlet "den mørke bakgrunn" for dåpen, er i 2008-liturgien plassert ved innledningen til forsakelsen og trosbekjennelsen. I 1981-liturgien var plasseringen i forbindelse med tekstlesningen. I utkastet fra 2008 vektlegges det kollektive framfor en individuell syndsforståelse: "Vi er mennesker under syndens og dødens vilkår, som i dåpen forenes med den oppstandne Kristus", ${ }^{x x}$ mens 1981-liturgien konstaterte at barna "er født med menneskeslektens synd og skyld." ${ }^{{ }^{x i}}$ For så vidt kan man si at tendensen til kollektivisering av synden var til stede i 1981-liturgien. Det individuelle aspektet er enda tydeligere uttrykt i alterboken fra 1920. Der omtales dåpsbarna direkte som syndige: "Syndige menneskebarn som de er, under syndens og dødens lov." Formuleringen i alterboken av 1889 var enda et hakk sterkere: (...) dette Barn, som er undfanget i Synd og født i Misgjerning”. Denne formuleringen ble sløyfet $\mathrm{i}$ alterboken fra $1920 .^{\text {xxii }}$

Interessant er det å notere at ordlyden i døpeformelen i 2008-utkastet ble endret til $i$ Faderens og Sønnens og Den Hellige ånds navn. Som nevnt hadde preposisjonen til kommet inn i dåpsritualet i 1914. Hovedbegrunnelsen for endringen den gang var at preposisjonen var brukt i oversettelsen av Matt 28 i bibeloversettelsen fra 1904. Det har vært ulike meninger om hvordan preposisjonen eis skal oversettes. Den viktigste grunnen til at man i utkastet fra 2008 gikk tilbake til preposisjonen $i$, var at dette $\varnothing$ kumenisk var mest utbredt. Men det fikk da den konsekvens at begge formuleringer ble brukt i dåpshandlingen, da Matt 28 ble sitert etter den gjeldende bibeloversettelsen. ${ }^{\text {xxiii }}$

En annen endring var at Gustav Jensens formulering vedrørende dåpens virkning som følger etter dåpshandlingen, at Gud har tatt dåpsbarnet inn i sin "troende menighet", ble sløyfet til fordel for "kirke". Begrunnelsen var at formuleringen "troende menighet" lød altfor internt i den aktuelle kirkesituasjonen. ${ }^{\text {xxiv }}$

\section{1-liturgien}

Den endelige dåpsliturgien som Kirkemøtet vedtok i 2011 etter en lang høringsprosess, må sies på sentrale punkt å gå mot viktige endringer som var foreslått i 2008-utkastet. Mange 
kunne nok oppleve 2011-liturgien som et tilbakeslag i forhold til forslaget fra 2008. Imidlertid beholdt man den treleddede strukturen som ble innført i 2008-liturgien. Takkemomentet ved mottakelsen var til stede også i 2011-liturgien, men en viktig forskjell er at fokuset igjen ble lagt på at det er menigheten som tar imot dåpsbarnet: "Med takk og glede tar menigheten imot barnet/barna som i dag skal døpes i Guds hus”. Det skapelsesteologiske aspektet ble uttrykt i formuleringen: "Gud har gitt oss livet og skapt oss til fellesskap med seg", men umiddelbart etterpå fulgte imidlertid en påpekning av hva vi frelses fra: ”Etter sitt ord og løfte tar Gud imot oss i dåpen og frelser oss fra synd og død”. ${ }^{\mathrm{xxv}}$ Syndsaspektet er kollektivt poengtert gjennom pronomenet "oss" - det uttrykkes ikke direkte i relasjon til dåpsbarnet. Videre ble Joh. 3,16 tatt inn tilsvarende 1981-liturgien og plassert under mottakelse til dåpen.

Mark 10 (Jesus og barna) har i 2011-liturgien den samme tidlige plasseringen som i 2008liturgien. Takkebønnen med tre alternativer er også beholdt. Deretter følger så den andre tekstlesingen, som er dåpsbefalingen (Matt 28,18-20).

Det er videre tre alternativer til bønn ved døpefonten. Gjennomgående for alle tre er at det poengteres hva vi frelses fra. "Evige Gud, vi takker deg for frelsen i den hellige dåp", heter det i det tredje bønnealternativet, "der du frir oss fra mørkets makt og gjør oss til lysets barn". xxvi Dette sies om "oss", altså mennesket som en kollektiv størrelse. Men samtidig er det vanskelig å unngå å oppfatte dette som et utsagn om det udøpte barnets status: det er bundet av "mørkets makt". Dette negative menneskesynet korresponderer med tanken om at man blir Guds barn i dåpen, slik det uttrykkes etter selve dåpshandlingen. Her har man tatt inn igjen formuleringen fra 1981-liturgien: ’Den allmektige Gud har nå gitt deg sin hellige Ånd, gjort deg til sitt barn og tatt deg inn i sin troende menighet. Guds styrke deg med sin nåde til det evige liv." "xxvii Formaningen til fadderne kommer etter dåpen som i 2008-liturgien.

\section{7-liturgien}

2011-litrugien fikk ikke noe langt liv i vår kirke. Ved evalueringen av gudstjenestereformen kom det fram kritiske merknader til den. Det ble pekt på at den var for lang og ordrik, tung og gjentagende. Ikke minst i lys av synkende dåpstall, og at man gjerne vil ha dåp i gudstjenesten, reiser det spørsmålet om forenkling. Det ble lagt opp til en revisjon og en ny omfattende høringsprosess, som ble gjennomført i 2016. Ny dåpsliturgi ble vedtatt av Kirkemøtet i 2017. Liturgien er blitt forkortet og språket strammet inn og forbedret. 
Det er ikke menigheten som tar i mot barna til dåp, slik som i 2011-liturgien og 1981liturgien, men Gud. Formuleringen lyder: "Med takk og glede bringer vi i dag dette barnet til Gud i den hellige dåp. I dåpen tar Gud imot oss og forener oss med den korsfestede og oppstandne Jesus Kristus". xxviii Ett av de store diskusjonstemaene i forbindelse med vedtaket av 2017-liturgien var hvorvidt Joh. 3,16 skulle være kan-ledd eller må-ledd i liturgien. Skriftstedet kom inn med 1981-liturgien, ble tatt ut i 2008-utkastet og gjeninnført i 2011. Etter Kirkemøtets vedtak er Joh. 3,16 et kan-ledd i den nye dåpsliturgien. Det har vært anført at bibelversets vektlegging av fortapelse contra evig liv kommuniserer dårlig som del av mottakelsen til dåp, hvor feiringen av livet og takken for livets store gave er det som bør fremheves. Deretter følger Mark 10 (Jesus og barna), så en takkebønn som understreker det skapelsesteologiske aspektet:

Evige Gud, du som gir liv til alt som lever og har skapt oss i ditt bilde: Vi takker deg for NN. De er dyrebare i dine øyne. Omslutt dem med din kjærlighet og gi dem et hjem i din kirke. Amen. ${ }^{x x i x}$

Riktignok tjener den siste delsetningen til å innsnevre det perspektivet til kirken. Fadderformaningen - under overskriften "Fadderansvaret" - er igjen plassert før selve dåpshandlingen. Plasseringen etter dåpen, innført med 2008-utkastet, var blitt kritisert i mange av høringssvarene. De konkrete opplistingene av hva fadderansvaret innebærer, er beholdt tilsvarende som tidligere. Utfordringene er dermed de samme som ved 1981-liturgien. Spørsmålet er i hvor stor grad fadderforpliktelsene kommuniserer med dem som bringer barna sine til dåp. Blir de for interne og indrekirkelige i forhold til folkekirkemenigheten? Hvor realistisk er det at foreldre og faddere vil lære barna å bruke nattverden, hvis de ikke gjør det selv? På den andre side ser man at ved økende bruk av intinksjon ved nattverdsfeiringen, synes flere i dåpsfølget å delta. Man kan imidlertid spørre om forpliktelsen på å oppdra barna i den kristne tro kan ivaretas på andre måter?

Dåpens "mørke bakgrunn" uttykkes ved at forsakelsen er beholdt som tidligere. I bønnen som innleder dåpshandlingen takker man Gud for dåpsvannet som "ved ditt ord er en nådens kilde, der du tilgir oss vår synd, frelser oss fra syndens makt og gir oss løfte om det evige liv". Som i tidligere liturgier uttrykkes synden og frelsen i kollektive kategorier ved bruk av vi- 
formuleringer. Videre heter det at"de som døpes reises opp til det nye livet med Jesus Kristus, vår Herre". ${ }^{\mathrm{xxx}}$

Fra 2011-liturgien videreføres preposisjonen til i forbindelse med dåpsformularet: dåpsbarnet døpes til Faderens og Sønnens og Den Hellige Ånds navn. Det har vært en viss debatt om man i stedet skulle bruke $i$, slik det het i dåpsritualet før 1914 og slik utkastet fra 2008 gjeninnførte. Den viktigste grunnen til at man har valgt å gå tilbake til å bruke preposisjonen til, er nok at det samsvarer bibeloversettelsen.

I velsignelsesønsket umiddelbart etter dåpshandlingen har man gått bort fra formuleringen om at man er blitt Guds barn i dåpen. I stedet anvendes formuleringen at den allmektige Gud har "født deg på ny", en formulering som kan sies å korrespondere med den ovennevnte uttrykksmåten at de døpte reises opp til det nye livet med Kristus. Fortsatt heter det at dåpsbarnet blir tatt inn i "den troende menighet", en formulering som har sin opprinnelse i Gustav Jensens revisjon i 1914. Utfordringen som denne uttrykksmåten reiser, blir dermed videreført også med den nye liturgien.

Til forskjell fra 2011-liturgien er det kommet inn et ledd som heter "Bønn og lovprisning" med tre bønnealternativer hvor man takker for dåpen og ber for dåpsbarna og deres framtid. ${ }^{\text {xxi }}$ Denne bønnen kan for øvrig leses under menighetens forbønn.

Med tanke på kirkesynet er det riktig å si at også den siste revisjonen av dåpsliturgien peker i litt forskjellige retninger. Det skapelsesteologiske perspektivet er kommet sterkere inn, og her har det skjedd en avgjørende endring sett i et lengre historisk perspektiv. Her var 2008utkastet er viktig gjennombrudd. Når det gjelder antropologien som uttrykkes i liturgien, kan man følge en klar utviklingslinje i retning av en kollektivisering av synden og behovet for frelse. Samtidig beholdes forsakelsen i forbindelse med trosbekjennelsen, en rest av det gamle eksorsismeleddet. Like fullt har det skjedd en utvikling av dåpsliturgien som vitner om et $\emptyset n$ ske om å ta den folkekirkelige virkeligheten på alvor. Det rimelig å se dette i sammenheng med at det er blitt en større oppmerksomhet og bevissthet om Den norske kirke som folkekirke. I tillegg har også synkende dåpstall bidratt til en økende bevissthet om hvordan man møter mennesker som kommer med barna til dåp. 
Samtidig videreføres flere elementer som peker i en annen retning, for eksempel at dåpsbarnet opptas i "den troende menighet". Likeledes kan opplistingen av konkrete forpliktelser under "fadderansvaret" kanskje i enda større grad en tidligere virke fremmedgjørende på mange som bærer barna til kirkelig dåp, slik vi tidligere har vært inne på. Ikke alle som bærer barna til dåp eller er faddere, vil for eksempel kjenne seg komfortabel med et fadderansvar som går ut på å hjelpe dåpsbarnet "til å bruke Guds ord og delta i den hellige nattverd", slik at han eller hun "kan leve og vokse i den kristne tro". xxxii Samtidig ser vi mange eksempler på at stadig flere også fra dåpsfamiliene går til nattverd under dåpsgudstjenesten. Dette har blitt enklere ettersom nattverd med intinksjon har blitt vanligere.

\section{Litteratur}

Almås, K. et al.: Presterollen. En kvalitativ intervjuundersøkelse om det å være prest i Den norske kirke. Tapir, Trondheim 1989.

Balsnes, A. H. et al. (red.): Gudstjeneste à la carte. Liturgireformen i Den norske kirke. Verbum akademisk, Oslo 2015.

Brunvoll, A.: Den norske kirkes bekjennelsesskrifter. Lunde, Oslo 1972.

Dåpsliturgi og høringsdokument. Forslag til ny dåpsliturgi for Den norske kirke. Eide forlag, Stavanger 2008.

Flatø, L.: Den store liturgirevisjonen i vår kirke 1886-1926. En kirkehistorisk unders $\varnothing$ kelse. Land og kirke/Gyldendal, Oslo 1982.

Fæhn, H.: Gudstjenestelivet i Den norske kirke. Fra reformasjonstiden til våre dager. Universitetsforlaget, Oslo 1994.

Grimelund, A.: Forelæsninger over practisk Theologie, i kort Sammendrag. Feilberg \& Landmarks Forlag, Christiania 1856.

Gudstjeneste for Den norske kirke. Eide forlag, Stavanger 2011.

Gudstjenestebok for Den norske kirke. Del II: Kirkelige handlinger. Verbum, Oslo 1992.

Holdt, J.: Niels Johannes Holm 1778-1845. Et blad af Brødremenighedens historie. Lunde, Bergen 1937. 
Kong Christian den Siettes Forordning, angaaende den tilvoxende Ungdoms Confirmation og Bekraftelse udi deres Daabes Naade. Friderichsberg, 1736. Skolehistoriske aktstykker. Nr. 24. Oslo 1990.

Mørreaunet, K.: Dåpens nødvendighet til frelse i Den norske kirkes dåpsliturgi. Spesialavhandling, Det teologiske Menighetsfakultet, Oslo 2012.

Nordkil, A.-H.: Endring i liturgi - endring i teologi? En studie av endringene i Den norske kirkes dåpsliturgi fra 1920-2008. Masteroppgave i religionsvitenskap. Universitetet i Troms $\varnothing$ 2011.

Ordning for Dåp i hovedgudstjeneste. Vedtatt av Kirkemøtet 2017:

https://kirken.no/globalassets/kirken.no/om-troen/gudstjeneste---

liturgi/daapsliturgi_2017_bokmaal.pdf [lesedato 18.08.2017].

Wisløff, C.Fr.: Norsk kirkehistorie. Bind III. Lutherstiftelsen, Oslo 1971.

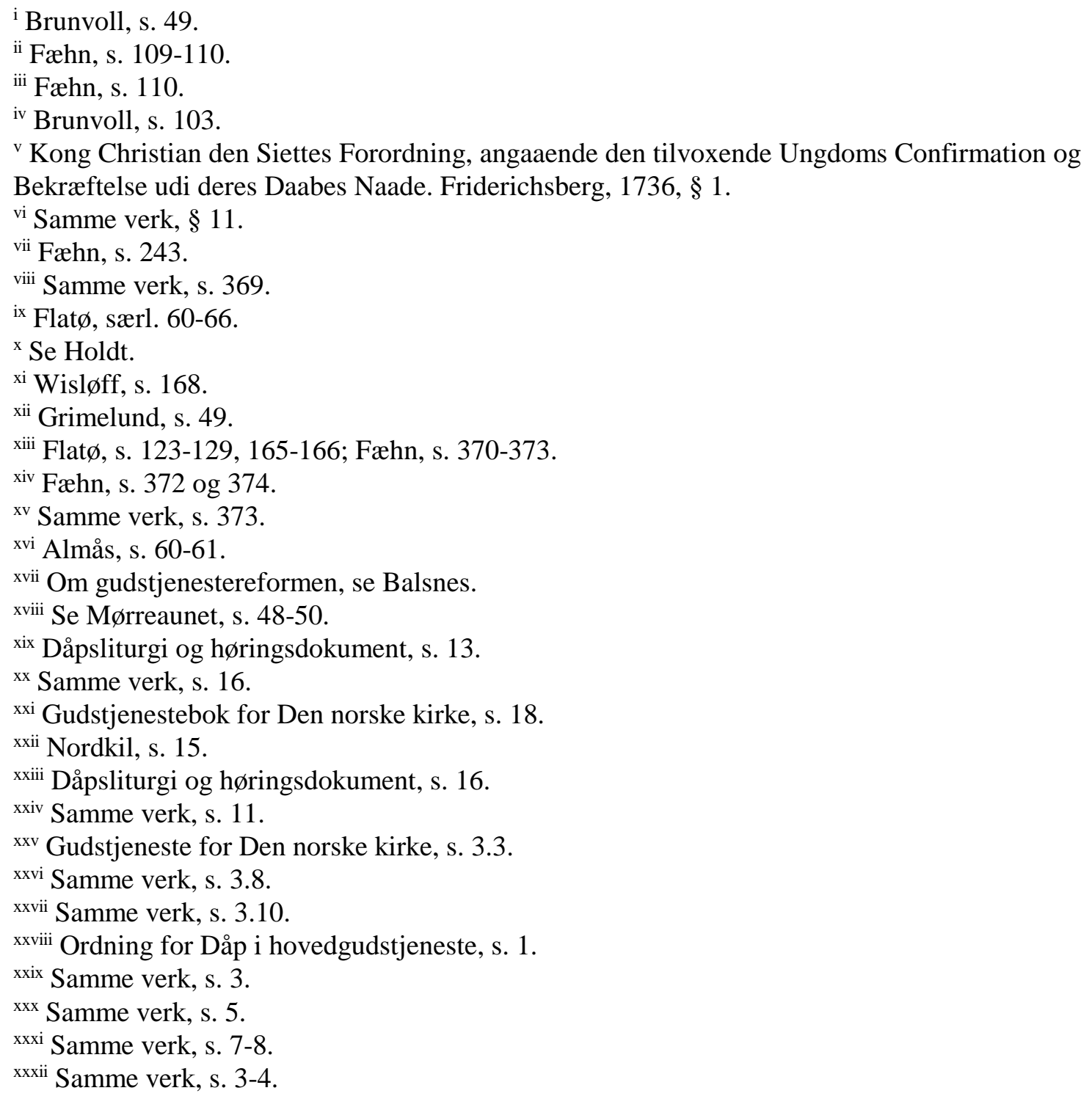

